\title{
Egészséghasznosság-mérés időalku módszerrel Magyarországon
}

\author{
Balázs Péter György ${ }^{1,2}$ - Brodszky Valentin dr. ${ }^{1}$ - Rencz Fanni dr. ${ }^{1,3}$ \\ ${ }^{1}$ Budapesti Corvinus Egyetem, Egészségügyi Közgazdaságtan Tanszék, Budapest \\ ${ }^{2}$ Budapesti Corvinus Egyetem, Gazdálkodástani Doktori Iskola, Budapest \\ ${ }^{3}$ Magyar Tudományos Akadémia, Prémium Posztdoktori Kutatói Program, Budapest
}

\begin{abstract}
Bevezetés: Az időalku (time trade-off) egy nemzetközileg széles körben alkalmazott életminőség- és egészséghasznosság-mérési módszer. Az időalkuval mért hasznosságértékek az egészségügyi technológiák költséghatékonysági vizsgálatakor az életminőséggel korrigált életév (quality-adjusted life year, QALY) mutatószám számítására használhatók. Kevés ismerettel rendelkezünk arról, hogy Magyarországon milyen betegségekben állnak rendelkezésre időalkuval mért hasznosságértékek.

Célkitüzés: Célunk szisztematikus irodalmi áttekintés keretében összefoglalni és katalogizálni az időalku módszerrel mért hasznosságértékeket közlő publikációkat Magyarországon.

Módszer: 2020 januárjában szisztematikus folyóirat-keresést végeztünk a PubMed, Web of Science és Matarka elektronikus adatbázisokban. Beválogatási kritériumaink a következők voltak: (1) eredeti közlemények, melyek (2) időalku módszerrel mértek hasznosságértéket, és (3) magyarországi mintán mért adatokat közöltek.

Eredmények: 9 eredeti közleményt válogattunk be, amelyek összesen 7 krónikus betegségben (Crohn-betegség, időskori maculadegeneratio, krónikus migrén, pemphigus, psoriasis, primer dysmenorrhoea és rheumatoid arthritis) 23 egészségi állapot hasznosságát határozták meg. A kutatások mintanagysága 108 és 1996 fó között alakult. Két kutatás betegcsoportokat vizsgált, kettő az általános populációt, és három vizsgálatban szerepelt mindkettő. Hat kutatás használta a hagyományos időalku valamelyik formáját, egy pedig az összetett időalku módszert. Egy kutatásban szerepelt 'rosszabb a halálnál' válaszlehetőség. A leggyakrabban alkalmazott időtáv a standard 10 év volt (71\%). Az egyes állapotok hasznosságának átlaga 0,34 (kezeletlen pemphigus vulgaris) és 0,94 (enyhe primer dysmenorrhoea) között változott. A 'non-traderek' aránya az egyes kutatásokban 0 és $29 \%$ között változott.

Következtetések: Egyre több krónikus betegségben elérhetők a magyar társadalom vagy betegek preferenciáin alapuló egészséghasznosság-értékek. A hazai időalku-vizsgálatok többsége megfelel a nemzetközi minőségi követelményeknek. Az időalku módszer alkalmazása javasolt más krónikus állapotokban is, a felmért hasznosságértékek segíthetik az egészségügyi technológiákkal kapcsolatos finanszírozói döntéshozatalt.
\end{abstract}

Orv Hetil. 2021; 162(14): 542-554.

Kulcsszavak: időalku, egészséghasznosság, életminőséggel korrigált életév, QALY, költséghatékonyság

\section{Health utility measurement by time trade-off method in Hungary}

Introduction: Time trade-off (TTO) is a widely used method to assess health-related quality of life and health utilities for economic evaluations of health technologies. Little is known about the use of TTO in the Hungarian context. Objective: To systematically summarize the existing literature on the method in Hungary.

Method: In January 2020, we conducted a systematic literature search in three electronic databases (MEDLINE, Web of Science and the Hungarian Periodicals Table of Contents Database). Our inclusion criteria were: (1) original publications, which (2) measured utilities by using TTO, (3) from a Hungarian sample.

Results: Nine publications containing seven original studies were included that reported utilities for 23 different health states in seven chronic diseases (age-related macular degeneration, chronic migraine, Crohn's disease, pemphigus, primary dysmenorrhoea, psoriasis and rheumatoid arthritis). Sample sizes ranged from 108 to 1996 respondents. Two studies used general population samples, another two used patient groups and three studies used both. Six studies used a form of conventional TTO and one used composite TTO method. The most frequent timeframe was 10 years $(71 \%)$. The lowest mean utility was 0.34 (uncontrolled pemphigus vulgaris), while the highest was 0.94 (mild primary dysmenorrhoea). The overall proportion of non-traders ranged between 0 and $29 \%$ across studies. 
Conclusions: A growing number of studies are using TTO to assess utilities for chronic conditions from the general population or patients in Hungary. The majority of Hungarian TTO studies have met international quality standards. The assessment of TTO utilities is recommended also in other chronic conditions to assist health technology assessment.

Keywords: time trade-off, health utility, quality-adjusted life year, QALY, cost-effectiveness

Balázs PGy, Brodszky V, Rencz F. [Health utility measurement by time trade-off method in Hungary]. Orv Hetil. $2021 ; 162(14): 542-554$.

(Beérkezett: 2020. szeptember 13.; elfogadva: 2020. október 8.)

\begin{abstract}
Rövidítések
BTD = (better-than-dead $)$ 'jobb a halálnál'; DLQI = (Dermatology Life Quality Index) Bőrgyógyászati Életminőség Index; $\mathrm{EQ}-5 \mathrm{D}=\mathrm{az}$ egészségi állapotot értékelő kérdőív; GDP = (gross domestic product) bruttó hazai termék; NICE $=(\mathrm{Na}-$ tional Institute for Health and Care Excellence) Az Egészség és Klinikai Kiválóság Nemzeti Intézete (Egyesült Királyság); PRISMA $=($ Preferred Reporting Items for Systematic Reviews and Meta-Analyses) szisztematikus áttekintések és metaanalízisek preferált jelentési tételei; QALY $=$ (quality-adjusted life year) életminőséggel korrigált életév; $\mathrm{SD}=$ standard deviáció; TTO $=($ time trade-off $)$ időalku; $\mathrm{WHO}=($ World Health Organization) Egészségügyi Világszervezet
\end{abstract}

A krónikus betegségek egész életen át tartó jellegük miatt jelentős egészségveszteséget okoznak, és nagymértékben megterhelik a betegeket, a társadalmat és az egészségügyi rendszert. A krónikus betegségek mind a várható élettartamot, mind az egészséggel összefüggó életminőséget (a továbbiakban: életminőség) csökkenthetik [1]. Az életminőség mérésének két alapvető módszerét különíthetjük el: az egészségi állapotot méró életminőség-kérdőíveket és a hasznosságmércéket. Az egészséghasznosság fogalma valamilyen egészségi állapot értékét vagy preferáltságát jelenti egy olyan skálán, amelyen a teljes egészséget 1 -nek, míg a halált 0 -nak tekinthetjük $[2,3]$. A negatív hasznosságok a halálnál roszszabbra értékelt egészségi állapotokat jelentenek. Az egészséghasznosságok mérésének kiemelt jelentősége van a klinikai és a finanszírozói döntések támogatásában [4]. Klinikai körülmények között a hasznosságmérés alkalmas az egyes betegségekkel összefüggő betegségteher nagyságának vizsgálatára és az egészség értékének a betegek nézőpontjából történő közvetlen meghatározására. Klinikai vizsgálatokban egyre többször szerepel végpontként valamilyen hasznosságmérce, amely egyszerre teszi lehetôvé az egyes terápiák klinikai és gazdasági hasznának értékelését [5].

A hasznosságok felhasználhatók az egyes egészségügyi technológiák költséghatékonysági vizsgálata során az életminőséggel korrigált életévek (quality-adjusted life year, QALY) számítására [6]. A QALY egyetlen mutatószámban kombinálja az élettartamban (túlélés) és az életminőségben (hasznosság) bekövetkezett javulást. Egy teljes egészségben töltött életév 1 QALY-val egyenértékú. A QALY annak vizsgálatára szolgál, hogy hogyan érjünk el minél kisebb gazdasági ráfordításból minél nagyobb (vagy egységnyi) egészségnyereséget - hozzásegítve a finanszírozási döntéshozót a különböző egészségügyi beavatkozások közötti választáshoz. A finanszírozási küszöbérték azt mutatja meg, hogy egy társadalom vagy finanszírozó legfeljebb mekkora összeget hajlandó egy QALY-ért fizetni. Az Egészségügyi Világszervezet (WHO) az adott országra vonatkozó, egy főre eső bruttó hazai össztermék (GDP) egy-háromszorosát javasolja igazodási pontnak a finanszírozási küszöbérték meghatározásához $[7,8]$. Magyarországon jelenleg az egy fơre eső GDP háromszorosánál alacsonyabb Ft/ QALY-val bíró egészségügyi technológiák tekinthetők költséghatékonynak (15,4 millió Ft/QALY - 2019) [9].

A QALY alapját képező hasznosságértékek különböző populációktól származhatnak, így a társadalom tagjaitól, a vizsgált betegségekben érintettektől, a betegek gondozóitól vagy egészségügyi szakemberektől. Az egészségügyi technológiák gazdasági elemzése során azonban a legtöbb országban - így Magyarországon is - a felnőtt társadalom tagjai körében felmért hasznosságértékek a mérvadók [8-10]. A megfontolás hátterében elsősorban az áll, hogy a társadalombiztosítási hozzájárulás révén a felnőtt társadalom viseli az állami fenntartású egészségügyi rendszer terheit, így elvárható, hogy az ó preferenciáik jussanak érvényre az egészségügyi forrásallokációs döntések során [11].

Az egészséghasznosságok mérésére direkt és indirekt módszerek alkalmazhatók. A direkt módszer során a válaszadó közvetlenül a saját egészségét vagy jól definiált elképzelt állapotokat értékel. Az indirekt hasznosságmérésnél a válaszadó a saját egészségi állapotát egy olyan kérdőíven értékeli, amelyen az egyes válaszok kombinációjához korábbi felmérésekben kidolgozott, társadalmi preferenciákon alapuló értékkészlet alapján hasznosságértékek társíthatók [5]. Példák a direkt hasznosságmérési technikákra: az időalku (time trade-off), a standard játszma (standard gamble) vagy a vizuális analóg skála. $\mathrm{Az}$ indirekt hasznosságmérésre alkalmas életminőségkérdőívek közé sorolhatók az EQ-5D-kérdőívek, a Short Form 6D, a Quality of Well-Being scale és a Health Utilities Index [12]. 
Nemzetközi szinten a leggyakrabban alkalmazott direkt hasznosságmérési módszer az időalku [13, 14]. Ezen kívül a világszerte leggyakrabban használt indirekt hasznosságmérési módszer, az EQ-5D-kérdőív hasznossági értékkészleteinek többsége is az időalku módszeren alapul [10, 15-17]. Az Egyesült Királyságban a National Institute for Health and Clinical Excellence (NICE) által 2004 és 2008 között áttekintett egészségügyi technológiaelemzési beadványok többsége $(54 \%)$ az időalku módszert használta (beleszámítva az indirekt hasznosságmérést alkalmazó elemzések esetén a hasznossági értékkészleteket) [18]. Ugyanez Magyarországon 2004 és 2011 között 33\% volt [17, 19].

A hazánkban leggyakrabban alkalmazott indirekt hasznosságmércével, az EQ-5D-kérdőívvel történt kutatásokat korábbi összefoglaló közleményünkben áttekintettük [10, 20-23]. Kevés ismerettel rendelkezünk arról, hogy Magyarországon milyen betegségekben állnak rendelkezésre direkt módon mért hasznosságértékek, különös tekintettel az időalkuval történt vizsgálatokra. A jelen dolgozat célja, hogy szisztematikus irodalmi áttekintés keretében összefoglalja és katalogizálja az időalku módszerrel mért hasznosságértékeket közlő közleményeket. A folyóirat-kereséssel párhuzamosan szeretnénk áttekinteni az időalku főbb típusait és azok módszertani jellemzőit.

\section{Módszerek}

\section{Az idôalku módszer (time trade-off, TTO)}

Az időalku módszer alapja, hogy a válaszadót (beteg vagy a társadalom tagja) olyan döntésre kéri, amelyben ő kompromisszumot hoz egy vizsgált egészségi állapottal kapcsolatos vagy a saját egészségi állapotában megtapasztalt életminőség és az élettartam között. Az időalku tehát dilemmát állít a válaszadó elé: élhet rövidebb ideig teljes egészségben, vagy hosszabb ideig „tökéletlen” egészségi állapotban. A módszer feltevése, hogy minél súlyosabb egy állapot, az egyén annál több időt hajlandó feláldozni a teljes egészség eléréséért. A hasznosságértéket az alkufolyamat hívja elő: ennek során a válaszadó eldönti, mekkora időegységet hajlandó feláldozni, hogy elérje a teljes egészség állapotát $[2,3]$.

Több mint 30 éves alkalmazása óta az időalku módszere számtalan változatban elérhető, részben a módszer sokfélesége, részben a standardizálás hiánya miatt [14, 24]. Az utóbbi évtized metodológiai harmonizációs törekvései számos módszertani jellemzőt soroltak fel, amelynél számottevő különbségek lehetnek az egyes időalku-vizsgálatok között [25]. Ilyen az adatgyújtés módja, az időtáv, a legkisebb feláldozható időegység, a válaszadási formátum, a válaszlehetőségek száma, a megvizsgált állapotok száma és sorrendje, hogy elképzelt vagy megtapasztalt egészségi állapot szerepel-e a kérdésben, és hogy kik értékelik a hasznosságokat [25].
Az adatgyüjtés módja lehet önkitöltős, ezen belül papír- vagy internetalapú, illetve interjúztatói segítséggel vezetett, ezen belül személyes interjú vagy számítógéppel támogatott személyes interjú. Az idôtávot illető különbségek tekintetében a nemzetközi irodalomban legelterjedtebb 10 év mellett a leginkább a 20 évet rögzítő vagy a válaszadó statisztikailag várható élettartamát alkalmazó kutatások fordulnak elő [13]. A legkisebb feláldozható idôegység kutatástól függően a legtöbbször 1 nap és 1 év között változhat, ami a válaszadó időpreferenciáitól függően szintén befolyásolhatja az eredményeket. Az időalku válaszadási formátuma kétféle lehet: csak 'jobb a halálnál' értékelési lehetőség van, vagy lehetséges az egyes egészségi állapotokat a halálnál is rosszabbra értékelni. A válaszadási formátum határozza meg a hasznosságértékek tartományát, a 'jobb a halálnál' esetében 0-1, míg a 'rosszabb a halálnál' állapotban ezen kívül negatív hasznosságok is előfordulnak $(-1+1)$. Az összetett időalkuban a hasznosságok terjedelme -1-től 1-ig terjed. A felkínált válaszlehetôségek számát a kutató dönti el, nyílt kérdésben ez lehet akár korlátlan. A vizsgált egészségi állapotok lehetnek elképzeltek vagy a válaszadó által megtapasztaltak, vagy mindkettő - számuk kutatástól függően magas lehet, de csak ritka esetben több, mint 15 [26]. Az egészségi állapotok sorrendjének megválasztásában a kutatónak szintén van szerepe, a kérdőívben felsorolt állapotok sorrendje követhet kötött (bármilyen permutációban) vagy randomizált sorrendet. Az időalku-feladatban az egészségi állapotok értékelöi lehetnek az általános populáció tagjai vagy betegek (de egyazon kutatásban szerepelhet mindkét csoport is).

$\mathrm{Az}$ alábbiakban a magyarországi kutatásokban alkalmazott három időalku-formátumot mutatjuk be. Tekintsük példaként az 1 a ábrán szereplő hagyományos időalku-feladat leggyakoribb formáját, amelyben egy elképzelt egészségi állapot - vakság - hasznosságát szeretnénk

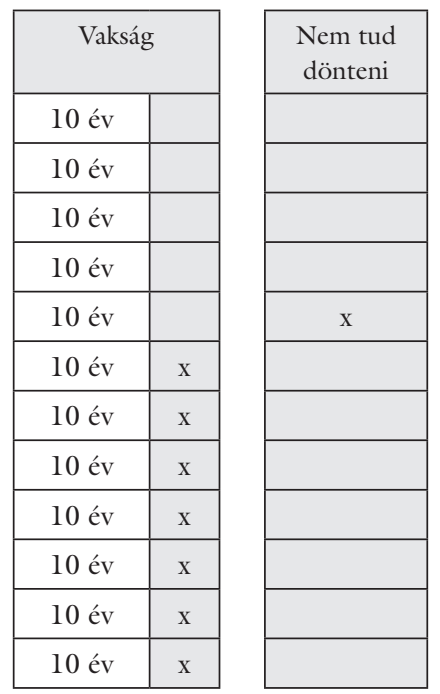

\begin{tabular}{|c|c|}
\hline \multicolumn{2}{|c|}{ Teljes egészség } \\
\hline $\mathrm{x}$ & 10 év \\
\hline $\mathrm{x}$ & 9 év 6 hónap \\
\hline $\mathrm{x}$ & 9 év \\
\hline $\mathrm{x}$ & 8 év \\
\hline & 7 év \\
\hline & 6 év \\
\hline & 5 év \\
\hline & 4 év \\
\hline & 3 év \\
\hline & 2 év \\
\hline & 1 év \\
\hline & 0 év = azonnali halál \\
\hline
\end{tabular}

\begin{tabular}{l|l} 
1. ábra & $\begin{array}{l}\text { Példa hagyományos időalku-feladatra } \\
\text { Forrás: [38] alapján - saját szerkesztés }\end{array}$
\end{tabular} 
megmérni. A válaszadókat elsőként megkérjük, képzeljék el, hogy vakon élnek pontosan 10 évet, amelyet követően meghalnak. Ezután az 1. ábrán szereplő táblázatban soronként két választási lehetőséget kínálunk fel a válaszadóknak. Az első sorban a két alternatíva, hogy a válaszadók vagy vakon élnek 10 évet, amelyet követően meghalnak, vagy ugyanennyi időt élhetnek teljes egészségben. Soronként lefelé haladva a teljes egészségben eltöltött idő fokozatosan csökken, 10 évtől egészen 0 évig (= azonnali halál). Azt a pontot, amelynél a válaszadók nem tudnak dönteni az adott állapotban töltött 10 év és a mellette szereplő, rövidebb időtartamú teljes egészség között, indifferenciapontnak nevezzük. A vizsgált egészségi állapot (a jelen esetben a vakság) hasznossága közvetlenül az indifferenciapontból számítható ki. Például ha egy válaszadó 10 év vakság és 7 év teljes egészség alternatívák mellett nem tud dönteni (másként fogalmazva: 10 éves időtávból 3 évet hajlandó feláldozni a vakság elkerüléséért), akkor az egészséghasznosság számítása a következőképpen történik (amelynél l a teljes egészség hasznossága):

$$
\begin{gathered}
7 \text { év } \times 1=7 \text { QALY }=10 \text { év } \times \text { vakság hasznossága } \\
\text { vakság hasznossága }=\frac{7 \text { év }}{10 \text { év }}=0,7
\end{gathered}
$$

Ezenkívül megemlítjük még a hagyományos időalku egy alternatív formáját is, az „egyválaszos indifferenciapont” módszerét, amelynél a válaszadónak azonnal meg kell neveznie a teljes egészségért feláldozandó életéveket, tehát az iteráció folyamata nagyban lerövidül.

Az összetett időalku (composite time trade-off) [27] módszer két részből áll: első része megegyezik a hagyományos időalkuval, ezt minden válaszadó használja; második részét azonban csak azok a válaszadók töltik ki, akik a hagyományos időalku-feladatban egy adott egészségi állapot helyett inkább az azonnali halált választják. A 'rosszabb a halálnál' döntési formátumban a válaszadó az adott egészségi állapotát megelőzve (vakság) kap 10 év teljes egészséget, így a 10 év egészség + 10 év adott állapot vs. 10 év teljes egészség kiindulópontból áldozhat fel időegységet. Tegyük fel, hogy a válaszadó ebben a formátumban 4 évet áldozna fel, ekkor az állapot egészséghasznossága:

$$
\begin{gathered}
6 \text { év } \times 1=6 \text { QALY = } 10 \text { év } \times \text { vakság hasznossága } \\
\text { vakság hasznossága }=\frac{6-10 \text { év }}{10 \text { év }}=-0,4
\end{gathered}
$$

Fontos említést tennünk az időalku módszer limitációiról is. Az időalku módszer számára kihívást jelent az enyhe (például enyhe rövidlátás), valamint az akut vagy rövid távon fennálló egészségi állapotok értékelése (például csonttörés) [28]. Módszertani szempontból a betegek eltérő életkora megnehezíti a megfelelő időtáv kiválasztását, a gyengébb általános kognitív képességek akadályozhatják a feladat megértését, illetve irodalmi adatok alapján különféle vallási meggyőződések és kulturális faktorok szintén befolyásolhatják az alkuhajlandóságot [29]. Kiskorúaknál etikai problémákat vethet fel a módszer alkalmazása [30]. Ezen kihívások feloldására többféle időalku-alternatíva jelent meg: a várakozás és az azonnali ellátás állapotai közti alku (waiting trade-off), vagy két tökéletlen állapot közti iteráció (chained time trade-off), átmeneti egészségi állapot krónikussá való átalakítása, a halál és az annál jobb állapot közti választás formátumának használata (BTD, better-than-dead method) [31], vagy az alvásalku (sleep trade-off), amelyben a hagyományos időalkuban szereplő 'halál' viszonyítási pontot egy nem pihentető alvásállapotra cserélik [24]. Az új technikák alkalmazása azonban innovatív jellegük ellenére szintén korlátokba ütközhet.

\section{Szisztematikus folyóirat-keresés}

A folyóirat-keresés során a Preferred Reporting Items for Systematic Reviews and Meta-Analyses (PRISMA) irányelvet követtük [32]. Az irodalomkeresés során két nemzetközi és egy hazai elektronikus adatbázisban kerestünk (PubMed, Web of Science, Matarka) 2020. január 13án. Kulcsszóalapú keresési stratégiát használtunk az időalku módszerhez kapcsolódó keresőszavak kombinálásával. Nem használtunk nyelvi korlátozásokat. A keresési stratégiát az Arber és mtsai által javasolt „keresési szúrő” alapján dolgoztuk ki [33]. A részletes kereséshez meghatároztuk a kulcsszavak logikai kapcsolatát és a stratégia folyamatát:

1. time trade off OR time trade-off OR TTO

2. utilities OR (utility AND [health OR index OR indices OR measure* OR weight* OR score* OR value* OR gain *])

3. QALY OR quality-adjusted life year

4. illness state* OR health state*

5. health gain*

6. \#1 OR \#2 OR \#3 OR \#4 OR \#5

7. Hungary OR Hungarian

8. \#6 AND \#7

A Matarka adatbázisában ugyanez a keresés magyar keresőszavakkal történt: időalku, hasznosság, TTO, egészségnyereség, QALY.

A szisztematikus szakirodalmi áttekintésbe beválogatott kutatások három kritériumnak kellett, hogy megfeleljenek: (1) eredeti közlemények, melyek (2) időalku módszerrel mértek hasznosságértéket, és (3) magyarországi mintán mért adatokat közöltek. A kutatásból kizárt közlemények ennek megfelelően azok voltak, melyek nem eredeti közlemények (például irodalmi áttekintések, konferenciaabsztraktok), nem az időalku témájában íródtak, vagy nem magyar mintán vizsgált adatokat tartalmaztak, illetve több országot magukban foglaló vizsgálatok esetén a magyar eredmények önállóan nem érhetők el. A keresési találatokat két szerző (B. P. Gy., R. F.) egymástól függetlenül tekintette át, 
először cím és absztrakt szerint, majd a beválogatott közleményeket teljes terjedelemben. Minden beválogatott közleményből kigyújtöttük a mintaelemszámot, a vizsgált populáció jellemzőit (betegcsoport vagy általános populáció, a válaszadók átlagéletkora, a nemek részaránya és a vizsgált betegség), a kutatásban használt időalku módszer jellemzőit (időtáv, feláldozható időegységek, a válaszlehetőségek száma és sorrendje), valamint a hasznosságeredményeket (átlag, szórás, medián, interkvartilis terjedelem, terjedelem, az ' 1 ' és ' $\leq 0$ ' válaszok és a 'non-traderek' aránya). Azon válaszadókat tekintjük 'non-trader'-nek, akik minden vizsgált állapotot 'l', azaz a teljes egészségnek megfelelő hasznosságra értékeltek, mert valamilyen okból nem hajlandók semennyi időt feláldozni.

\section{Eredmények}

\section{A beválogatott közlemények}

A három adatbázisban 634 találatot azonosítottunk, melyek közül a duplikátumok ( $83 \mathrm{db}$ ) kizárásra kerültek (2. ábra) [32]. A kizárási kritériumok figyelembevételével cím- és absztraktellenőrzés alapján eltávolítottunk 520 közleményt. A fennmaradó 31 találat tartalom-ellenőrzésen ment keresztül, amelynek során a közlemények teljes terjedelemben történő áttekintése után kizártunk további 22 publikációt (nem használt időalku módszert: $\mathrm{n}=21$, valamint nem tartalmazott önálló magyarországi adatot: $\mathrm{n}=1$ ). A három beválogatási kritériumnak 9 publikáció felelt meg [34-42].

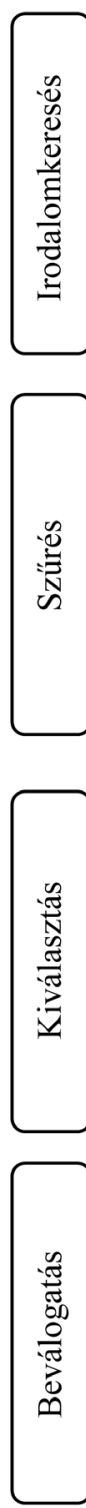

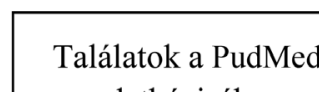
adatbázisában $(\mathrm{n}=345)$

\section{(Taien}

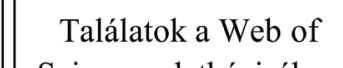

Science adatbázisában $(\mathrm{n}=252)$
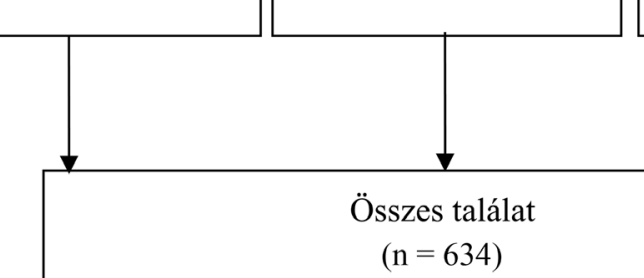

Összes találat $(\mathrm{n}=634)$

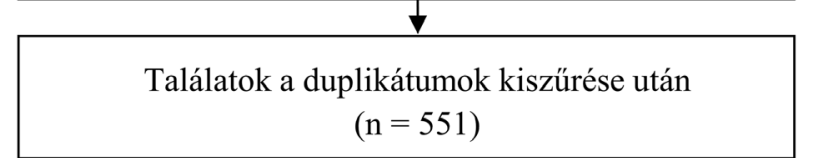

2. ábra

Nem eredeti közlemény vagy nem az időalku témájában íródott $(\mathrm{n}=520)$

beválogatott

közlemények

$(\mathrm{n}=31)$

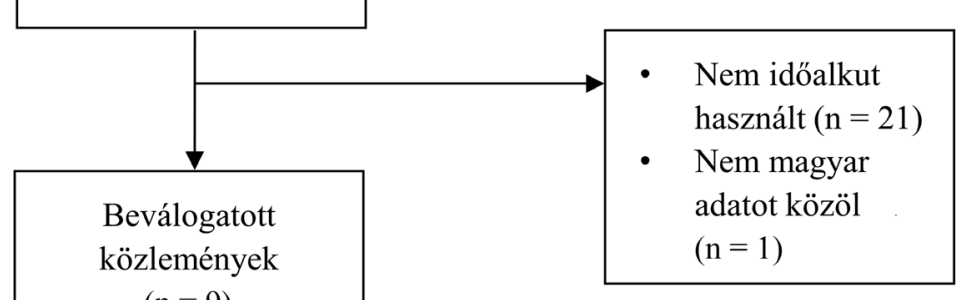

$(\mathrm{n}=9)$ 


\section{A beválogatott közlemények jellemzôi}

A 9 beválogatott közlemény összesen 7 önálló időalkukutatás eredményeit foglalja össze (1. táblázat [34-42]). Az első, időalku módszert tartalmazó életminőség-méréssel foglalkozó hazai kutatás 2011-ben jelent meg [35], a legfrissebb publikáció pedig 2019-ben [41]. Az áttekintett kutatások krónikus betegségek vizsgálatával foglalkoztak, a következő 7 krónikus betegségben végeztek hasznosságmérést: Crohn-betegség [41], időskori maculadegeneratio [36], krónikus migrén [39], pemphigus [34, 42], psoriasis [37], primer dysmenorrhoea [40] és rheumatoid arthritis [35]. Ezenkívül egy kutatásban a Bőrgyógyászati Életminőség Index (DLQI) bőrtünet-specifikus életminőség-kérdőív elemeivel leírt egészségi állapotok hasznosságát mérték fel az általános populáció és a psoriasisban érintett betegek körében $[37,38]$.

\section{A vizsgált populációk jellemzôi}

A vizsgált populáció részletes jellemzőit a 1 . táblázat foglalja össze. A kutatások mindegyike keresztmetszeti, nagymintás vizsgálat volt, a résztvevők száma 108 és 1996 fő között, az átlagéletkor 25,6 és 75,2 év között változott. A kutatásokban a nők aránya szintén meglehetősen nagy tartományban mozgott: 32,1\% (Crohn-betegség) és 100\% (primer dysmenorrhoea) között. Két kutatásban az általános populáció körében mértek hasznosságértékeket, ugyanennyi vizsgálat történt különböző betegcsoportokkal, és három kutatásban (Crohn-betegség, DLQI-val leírt állapotok és pemphigus) mind az általános populáció, mind betegcsoportok értékeltek egészségi állapotokat. Egyik általános populáció körében végzett felmérés sem volt reprezentatív a magyar társadalom egészére. A betegcsoportokat (is) vizsgáló felmérések közül a Crohn-betegséget, az időskori maculadegeneratiót, a psoriasist, a pemphigust és a rheumatoid arthritist érintő vizsgálatokban csak orvos által diagnosztizált betegek vehettek részt. Az általános populáció körében zajlott két felmérésben (krónikus migrén és primer dysmenorrhoea) a válaszadókat két csoportra osztották: (1) önbevallásos alapon betegségben érintett csoport és (2) nem érintett csoport.

\section{Az idöalku módszerek jellemzői}

Az adatgyüjtés módja négy esetben papíralapú önkitöltős, két esetben online önkitöltős forma volt, és egy önálló kutatás mindkét módszert alkalmazta. Három kutatás használta a hagyományos időalku módszert, egy az összetettet, és három vizsgálat alkalmazta a hagyományos időalku alternatív változatát, az egyválaszos indifferenciapont módszerét. Míg a Crohn-betegséget, a DLQI-val leírt egészségi állapotokat és a primer dysmenorrhoeát vizsgáló közlemények a hagyományos módszert alkalmazták, a pemphigusvizsgálatnál az összetett időalku módszert, az időskori maculadegeneratio, a rheumatoid arthritis és a krónikus migrén esetében pedig az egyválaszos indifferenciapont módszerét választották. A hét kutatásból kettő csak elképzelt egészségi állapotokat értékeltetett (krónikus migrén és primer dysmenorrhoea), és két felmérésben (rheumatoid arthritis és időskori maculadegeneratio) a betegek kizárólag saját megtapasztalt egészségi állapotukat értékelték. Három esetben - a Crohn-betegséget, a pemphigust és a psoriasist érintő vizsgálatokban - megtapasztalt és elképzelt állapotokat is értékeltek a betegek. Hét eredeti kutatásból öt közli az egészségi állapotok leírására szolgáló vignetták összeállításának módját, kettő a saját megtapasztalt állapotot vizsgálta. A Crohn-betegséget vizsgáló kutatásban gasztroenterológus szakorvosok és egészséggazdaságtani elemzők közösen tervezték meg a vignettákat, a pemphigusvizsgálatban szakirodalmi áttekintés és bőrgyógyász szakorvosi konzultáció alapján készültek az állapotleírások, míg a psoriasisvizsgálatban a DLQI bőrspecifikus életminőség-kérdőív elemeivel leírt állapotok jelentek meg a vignettákon. Két másik esetben (krónikus migrén és primer dysmenorrhoea) szakirodalmi áttekintés alapján készítették az állapotleírásokat.

Az időalku módszer kérdéseinek időtávja 10 évtől a szubjektív várható élettartamig terjedt. A leginkább használatos időtáv a standard 10 év $(\mathrm{n}=5,71 \%)$ volt. Az összetett időalku módszert alkalmazó pemphigusvizsgálatban a 'jobb a halálnál' válasz esetén az időtáv 10 év, míg a 'rosszabb a halálnál' válasz esetén $10+10$ év volt. Két kutatásban (időskori maculadegeneratio és rheumatoid arthritis) szubjektív várható élettartamot választottak időtávnak. A krónikus migrén időalku-vizsgálata során két különböző időtávot is használtak („még 20 évet él” és „80 éves koráig él”). Az időskori maculadegeneratiót és a krónikus migrént érintő vizsgálatokban nem a teljes egészség volt a hasznosságmérés végpontja, hanem a vizsgált betegségtől mentes állapot.

Az egyes vizsgálatokban a válaszlehetőségek száma (a válaszadó alkudható időegység-opcióinak száma) 8 és 22 között változott, három kutatásban (időskori maculadegeneratio, krónikus migrén, primer dysmenorrhoea) korlátlan választási lehetőség fordult elő ('egyéb válasz' formájában bármekkora időegységet feláldozhatott a válaszadó). Az alku folyamán feláldozható legkisebb időegység módusza 6 hónap $(\mathrm{n}=3,43 \%)$ volt. A hét kutatásból hat nem használta a 'rosszabb a halálnál' válaszlehetőséget, ezért ott a hasznosságértékek minimuma 0 volt. A vizsgált egészségi állapotok száma legalább egy (a saját) és maximum hét volt, de egy kutatáson belül sosem értékelt négynél több egészségi állapotot egy válaszadó (a próbafeladatokat nem számítva). A hét kutatás közül három meghatározta a felsorolt egészségi állapotok sorrendjét (kötött sorrend), míg kettő randomizálta az elképzelendő állapotokat. Két kutatás csak egy - a megtapasztalt - egészségi állapot hasznosságát mérte (rheumatoid arthritis és időskori maculadegeneratio). 


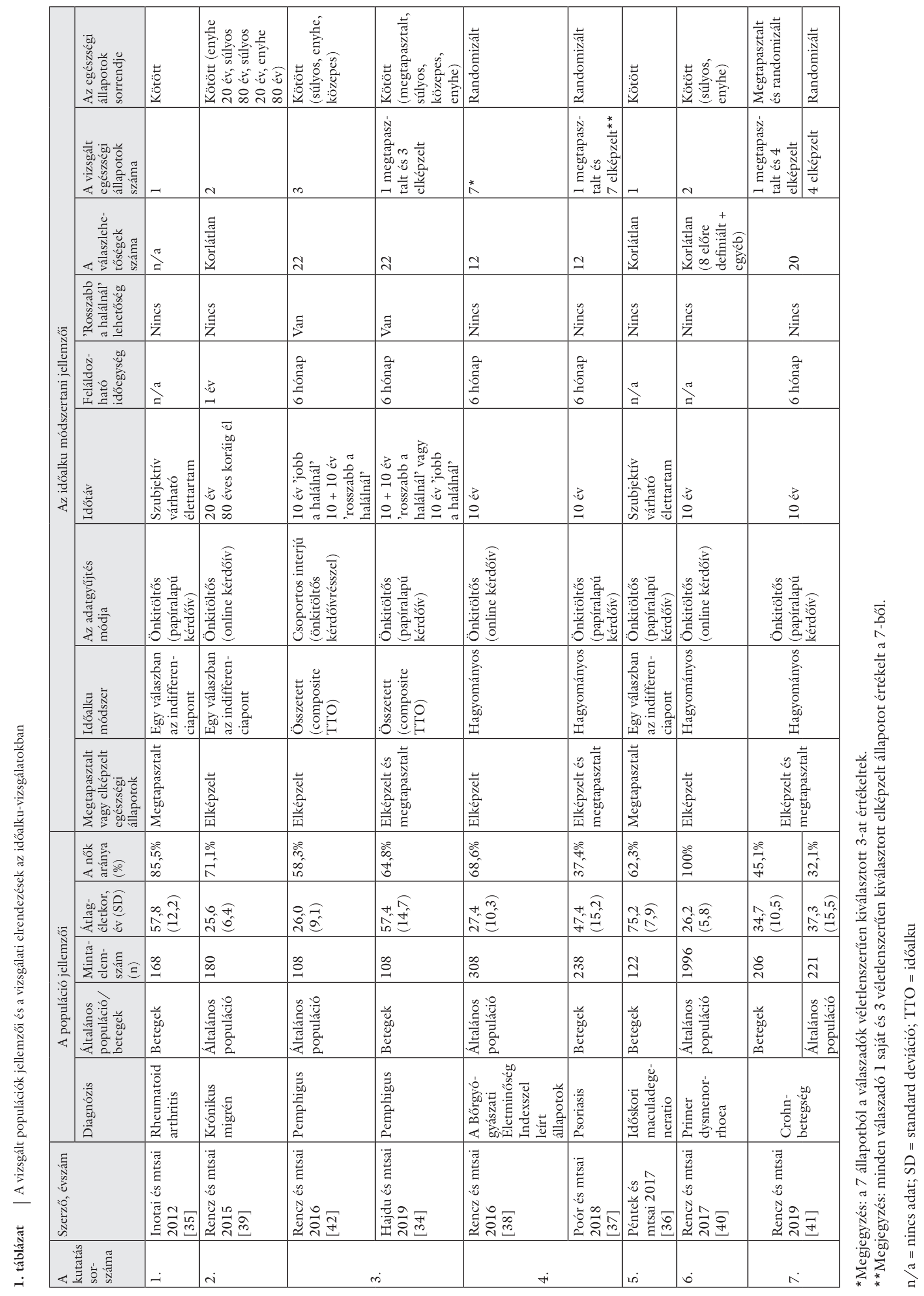




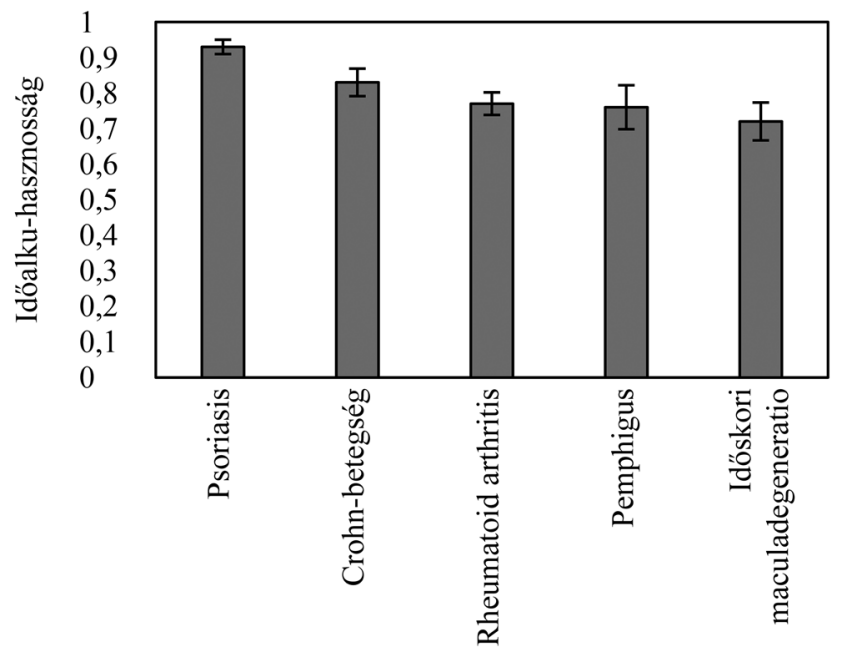

3. ábra $\quad$ Megtapasztalt egészségi állapotok hasznosságértékei betegcsoportok körében

\section{Idöalkuval mért hasznosságértékek}

A beválogatott hét kutatás összesen 23 egészségi állapot hasznosságát értékeltette (2. táblázat) [34-42]. A vizsgálatokban a hasznosságok átlaga 0,34 (kezeletlen pemphigus vulgaris) és 0,94 (enyhe primer dysmenorrhoea) között mozgott, átlaguk $0,74(S D=0,14)$ volt. A vizsgált krónikus állapotok hasznosságértékeinek összehasonlítását a 3. és a 4. ábra szemlélteti. Négy összehasonlítható krónikus betegség 11 elképzelt egészségi állapotából a betegcsoportok hasznossága két-két esetben alacsonyabb volt vagy megegyezett, hét esetben pedig magasabb volt, mint az általános populáció értéke.

Az 'l' válaszok aránya - amely azt mutatja meg, hogy a válaszadók hány százaléka értékelte az állapotokat a teljes egészséggel megegyezőnek (tehát nem volt hajlandó semennyi időt feláldozni az adott állapot elkerülésért) - az általános populációs minta körében $1 \%$ és $59 \%$ között változott, a betegcsoportok körében pedig ugyanez 14$58 \%$ volt. A kérdőívet kitöltők közül a 'non-traderek' aránya 0-tól 29\%-ig terjedt. Az általános populáción belül a „ $\leq 0$ ” hasznosságok aránya 0 és $12 \%$ között, míg a betegcsoportok esetén ugyanez 0 és $4 \%$ között mozgott. (A $\leq 0$ válaszok azt jelentik, hogy a válaszadó adott állapotnak tulajdonított hasznossága 0 , azaz indifferens a halál és az adott egészségi állapot között [ $[=0]$, vagy inkább meghalna, mint hogy az adott egészségi állapotban éljen $[<0])$.

\section{Megbeszélés}

Szisztematikus irodalomáttekintésünk során hét hazai, időalku módszerrel készült kutatás alapján 9 közleményt találtunk, összesen 7 krónikus betegségról. Közép-KeletEurópában az időalku-vizsgálatok számát Magyarország vezeti, a régió többi részén viszonylag csekély számú időalku-tanulmányt közöltek $[43,44]$. Fontos ugyanakkor megemlíteni, hogy a régióban Magyarország (2020), Lengyelország (2010 és 2019) és Szlovénia (2019) is rendelkezik időalkun alapuló, indirekt hasznosságmérésre alkalmas EQ-5D-értékkészletekkel, valamint Románia is megkezdte az értékkészlet kidolgozását $[10,17,45-$ 48].

A hazai időalku-kutatások egy kivétellel egy tudományos múhelyhez, a Budapesti Corvinus Egyetem Egészségügyi Közgazdaságtan Tanszékéhez köthetők. A beválogatott vizsgálatok többsége a krónikus betegségek két területére összpontosított: egyrészt olyan kórképekre, amelyek kezelésében az elmúlt két évtizedben hatékony, de magas költségú biológiai terápiák jelentek meg (Crohn-betegség, időskori maculadegeneratio, pemphigus, psoriasis és rheumatoid arthritis), másrészt krónikus fájdalmakkal járó állapotokra (krónikus migrén és primer

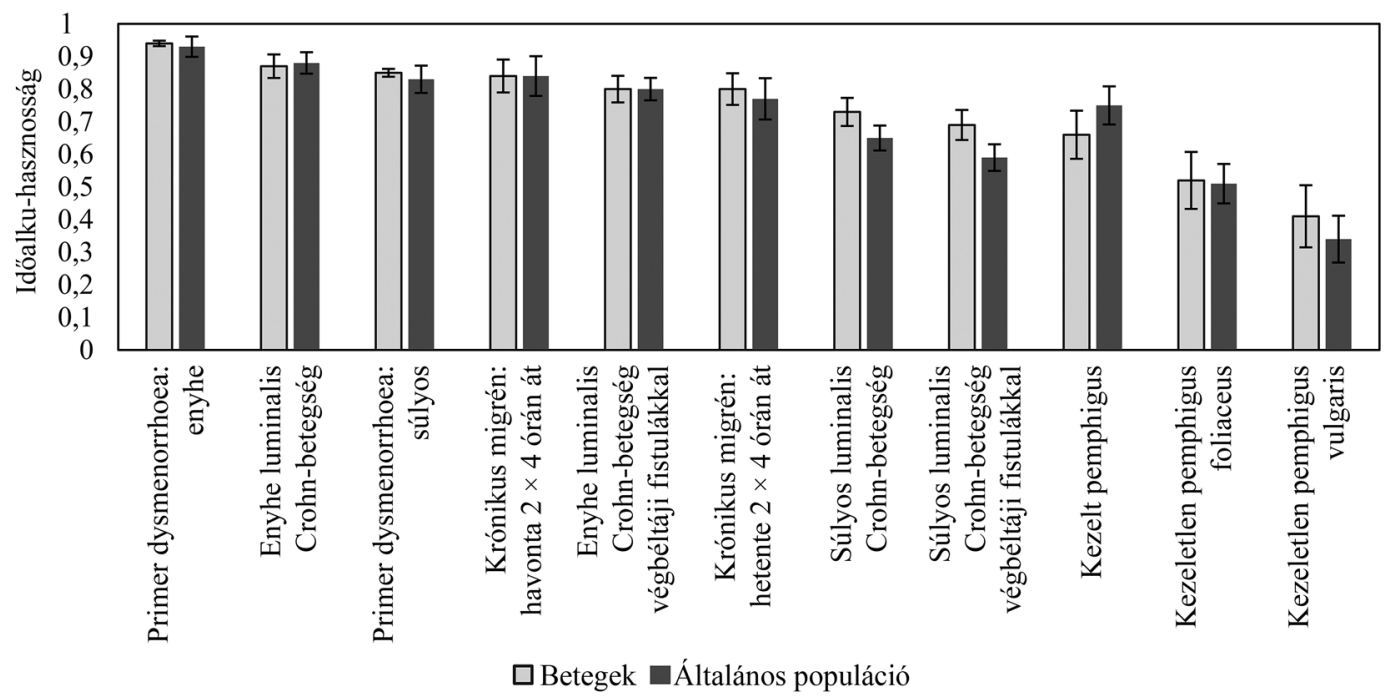

4. ábra | Elképzelt egészségi állapotok hasznosságértékei betegcsoportok és az általános populáció körében 


\begin{tabular}{|c|c|c|c|c|c|c|c|c|c|c|c|c|c|c|c|c|}
\hline 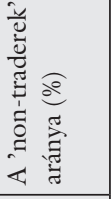 & $\stackrel{\pi}{\beth}$ & \multicolumn{8}{|c|}{$\stackrel{\partial}{=}$} & \multicolumn{3}{|c|}{ ठ̊ } & \multicolumn{4}{|c|}{ ‡े } \\
\hline 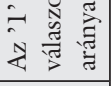 & $\stackrel{\approx}{\Rightarrow}$ & & $\stackrel{\text { ळे }}{\stackrel{一}{+}}$ & & 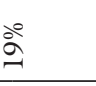 & & $\frac{\partial}{m}$ & & $\stackrel{\square}{ذ}$ & $\stackrel{\circ}{\circ}$ & $\stackrel{\circ}{\circ}$ & 仓ें & 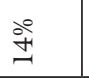 & $\stackrel{\circ}{\partial}$ & 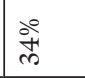 & î \\
\hline 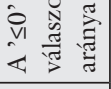 & $\stackrel{\pi}{=}$ & & 今े & & 8̊ & & ல̊ & & $\stackrel{\pi}{\beth}$ & 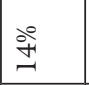 & ல̊ & ৯े & $\stackrel{\circ}{\circ}$ & さ̊ & ล้ & ले \\
\hline 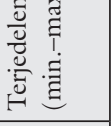 & ’ & & $\begin{array}{l}1 \\
1 \\
0 \\
0 \\
0 \\
0\end{array}$ & & $\begin{array}{l}1 \\
1 \\
0 \\
0 \\
0 \\
0\end{array}$ & & $\begin{array}{l}\text { I } \\
\\
0\end{array}$ & & $\vec{\jmath}$ & $\stackrel{ \pm}{T}$ & $\overrightarrow{ \pm}$ & $\underset{ \pm}{ \pm}$ & $\stackrel{ \pm}{+}$ & $\underset{ \pm}{ \pm}$ & $\underset{7}{7}$ & $\stackrel{7}{7}$ \\
\hline 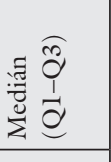 & $\stackrel{\approx}{\rightleftharpoons}$ & & 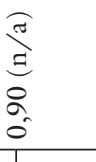 & & $\begin{array}{l}\tilde{\sigma} \\
\Xi \\
\vdots \\
\sigma \\
\delta \\
0\end{array}$ & & 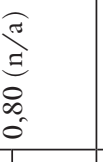 & & $\begin{array}{l}\Xi \\
\Xi \\
\Xi \\
0 \\
0 \\
0 \\
0\end{array}$ & 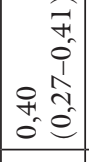 & 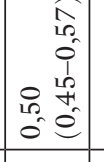 & $\begin{array}{rr} & \widehat{0} \\
0 \\
0 \\
0 & 0 \\
0 & 0 \\
0 & 0 \\
0 & 0 \\
\end{array}$ & $\begin{array}{l}\tilde{J} \\
\Xi \\
\vdots \\
\dot{0} \\
0\end{array}$ & \begin{tabular}{|l}
0 \\
$\Xi$ \\
$\Xi$ \\
0 \\
+1 \\
0
\end{tabular} & \begin{tabular}{|l}
0 \\
$\Xi$ \\
$\Xi$ \\
0 \\
10 \\
0 \\
0
\end{tabular} & $\begin{array}{c}0 \\
\Xi \\
\Xi \\
0 \\
\infty \\
0 \\
0\end{array}$ \\
\hline 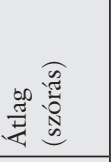 & $\begin{array}{l}\widehat{\vec{\jmath}} \\
\hat{e} \\
\hat{\hat{A}} \\
\hat{0}\end{array}$ & 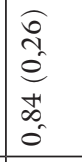 & 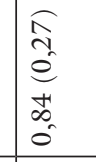 & 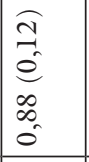 & $\begin{array}{l}10 \\
0 \\
0 \\
0 \\
2 \\
0 \\
0\end{array}$ & 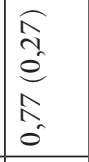 & $\begin{array}{l}0 \\
0 \\
1 \\
0 \\
0 \\
0 \\
0 \\
0 \\
0 \\
0\end{array}$ & \begin{tabular}{|c|}
$\widehat{O}$ \\
$\tilde{y}$ \\
0 \\
$\infty$ \\
$\infty$ \\
0 \\
0 \\
\end{tabular} & 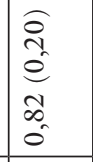 & 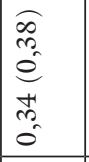 & \begin{tabular}{|c|c}
$\widehat{a}$ \\
0 \\
0 \\
$e$ \\
0 \\
0 \\
0 \\
0
\end{tabular} & $\begin{array}{l}\widehat{c} \\
0 \\
0 \\
0 \\
0 \\
0 \\
0 \\
0\end{array}$ & $\begin{array}{l}\hat{0} \\
0 \\
0 \\
0 \\
0 \\
0 \\
0 \\
0\end{array}$ & 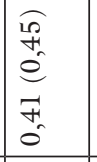 & 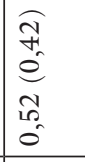 & $\begin{array}{l}0 \\
0 \\
0 \\
0 \\
0 \\
0 \\
0 \\
0 \\
0\end{array}$ \\
\hline$=$ & $\stackrel{\infty}{\stackrel{\infty}{\sim}}$ & 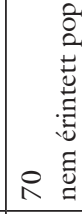 & 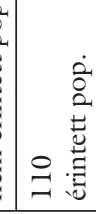 & 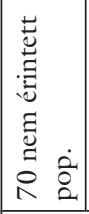 & | & 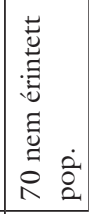 & 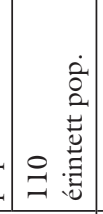 & 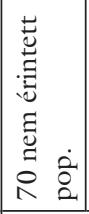 & 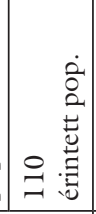 & $\stackrel{\infty}{\circ}$ & $\stackrel{\infty}{\varrho}$ & 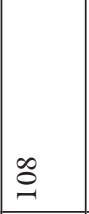 & 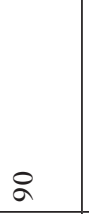 & $\triangleright$ & ळे & $\sigma$ \\
\hline 谞 & $\stackrel{*}{\rightleftharpoons}$ & & $\begin{array}{l}\overrightarrow{0} \\
\text { iे }\end{array}$ & & 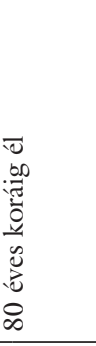 & & 离 & $\begin{array}{l}0 \\
0 \\
0 \\
0 \\
0 \\
0 \\
0\end{array}$ & 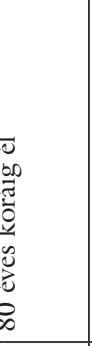 & 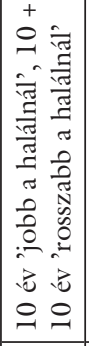 & 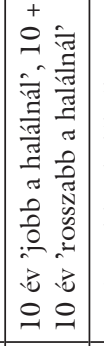 & 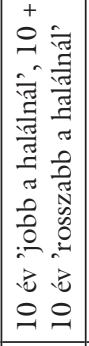 & 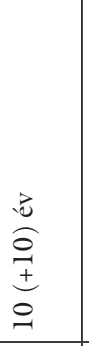 & 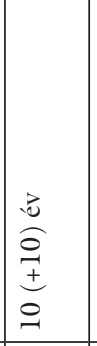 & $\begin{array}{l}\stackrel{\partial}{0} \\
\vdots \\
\pm \\
0\end{array}$ & $\begin{array}{l}\stackrel{b}{0} \\
\stackrel{0}{ \pm} \\
0 \\
\end{array}$ \\
\hline 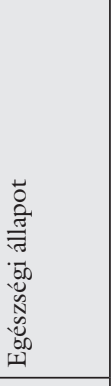 & 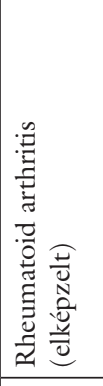 & & 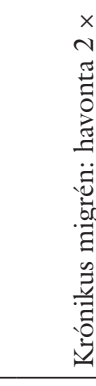 & 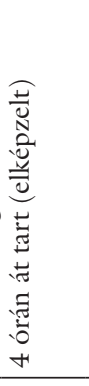 & & & 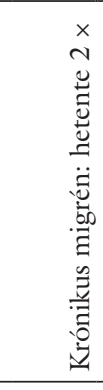 & & & 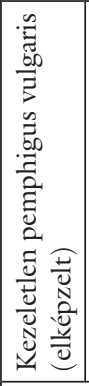 & 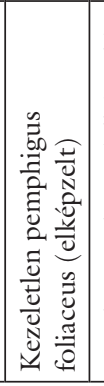 & 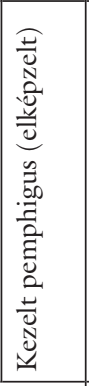 & 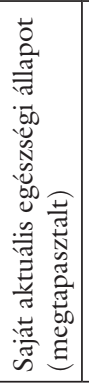 & 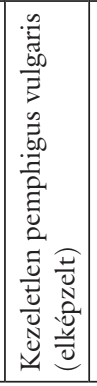 & 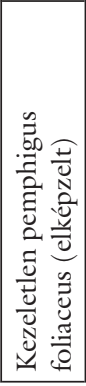 & 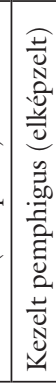 \\
\hline 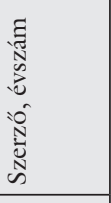 & 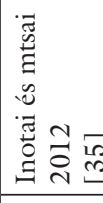 & & & & 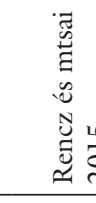 & 롱 & & & & & 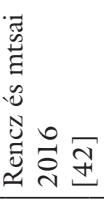 & & & 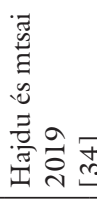 & & \\
\hline 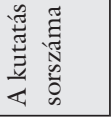 & $-\dot{ }$ & & & & & & & & & & & & & & & \\
\hline
\end{tabular}




\begin{tabular}{|c|c|c|c|c|c|c|c|c|c|c|c|c|c|c|c|c|c|c|c|c|c|c|c|c|c|c|}
\hline 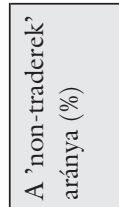 & \multicolumn{7}{|c|}{$\stackrel{\partial}{\stackrel{े}{ \pm}}$} & \multicolumn{8}{|c|}{ ڤें } & $\stackrel{\pi}{\Rightarrow}$ & \multicolumn{3}{|c|}{ ঐें } & \multicolumn{7}{|c|}{ 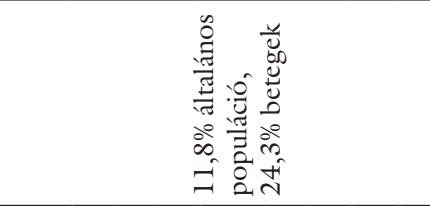 } \\
\hline 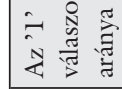 & ذे & సे & 今ે & $\stackrel{\circ}{\circ}$ & ڤ̊ำ & $\stackrel{\circ}{\exists}$ & å & & 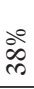 & ঔั & ஷें & ओं & $\stackrel{\circ}{\circ}$ & ओं & $\stackrel{े}{\frac{0}{\omega}}$ & $\stackrel{\pi}{\leftrightharpoons}$ & 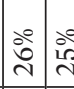 & ì & 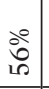 & ڤัं & $\begin{array}{ll}20 \\
0 \\
10\end{array}$ & $\mid \begin{array}{c}0 \\
\infty \\
\infty \\
\infty\end{array}$ & : & 高 & 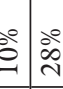 & a \\
\hline 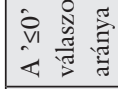 & ذิ & iั & ఏి & ذి & 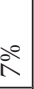 & 3 & $\infty$ & 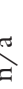 & ठें & هั & ठें & तें & $\stackrel{\overbrace{}}{2}$ & 8 & $\stackrel{\circ}{\circ}$ & $\stackrel{\pi}{\Rightarrow}$ & $\therefore$ & & अें & ふें & خे is & ले & ஓे & ลें & லे & 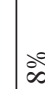 \\
\hline 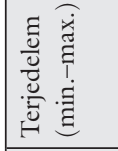 & t. & อ & $\vec{c}$ & $\vec{\jmath}$ & J & $\vec{d}$ & $\frac{1}{0}$ & $\frac{1}{d}$ & t) & $\vec{\jmath}$ & I & ] & ] & I & $\vec{\jmath}$ & 1 & J & 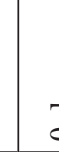 & iे & d & d & I & iे & $\vec{c}$ & & I \\
\hline 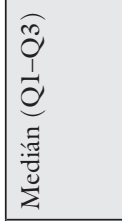 & $\begin{array}{ll} & \\
\Xi & \\
\vdots \\
0 \\
\infty \\
0 \\
0\end{array}$ & $\begin{array}{l}\Xi \\
\Xi \\
\vdots \\
\infty \\
0 \\
0\end{array}$ & $\mid \begin{array}{l}a \\
\vdots \\
\vdots \\
0 \\
0 \\
0 \\
0\end{array}$ & $\begin{array}{c}\text { J } \\
\Xi \\
0 \\
\infty \\
0 \\
0\end{array}$ & $\begin{array}{l}\tilde{\sigma} \\
\vdots \\
\vdots \\
0 \\
0 \\
0\end{array}$ & $\begin{array}{l}\tilde{\sigma} \\
\Xi \\
0 \\
0 \\
0\end{array}$ & $\begin{array}{l}\Omega \\
\Xi \\
0 \\
0 \\
0\end{array}$ & 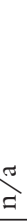 & $\begin{array}{l}\frac{1}{\alpha} \\
\hat{\sigma} \\
\text { Ln }\end{array}$ & é & $e_{0}^{0}$ & é & $\begin{array}{l}\widehat{I} \\
0 \\
0 \\
0 \\
0 \\
0 \\
0\end{array}$ & é & $\begin{array}{l}\widehat{1} \\
0 \\
\infty \\
0 \\
0 \\
0 \\
0\end{array}$ & $\stackrel{\pi}{\Rightarrow}$ & 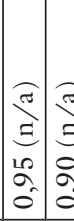 & है & 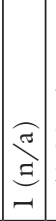 & $\begin{array}{l}\widehat{\overrightarrow{0}} \\
\infty \\
0 \\
0 \\
0 \\
-\end{array}$ & 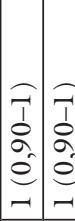 & 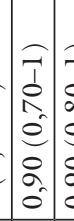 & $\begin{array}{l}\widehat{c} \\
0 \\
0 \\
0 \\
0 \\
0 \\
0 \\
0 \\
0\end{array}$ & 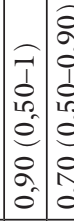 & 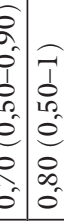 & 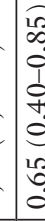 \\
\hline 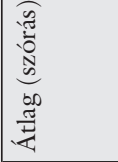 & 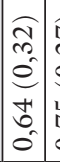 & 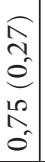 & 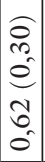 & $\begin{array}{l}\widehat{\mid} \\
0 \\
0 \\
0 \\
0 \\
0 \\
0 \\
0\end{array}$ & \begin{tabular}{l}
1 \\
$e$ \\
\multirow{2}{*}{} \\
0 \\
0 \\
0
\end{tabular} & & & $\begin{array}{l}e \\
\infty \\
\sigma\end{array}$ & है & 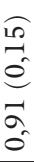 & & & & $\begin{array}{l}0 \\
0 \\
0 \\
0\end{array}$ & 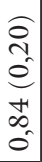 & 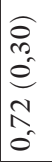 & 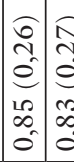 & $\begin{array}{l}0 \\
0 \\
0 \\
0 \\
0 \\
0 \\
0 \\
0 \\
0 \\
0\end{array}$ & $\left|\begin{array}{l}\hat{\sigma} \\
\hat{i} \\
e \\
e \\
2 \\
\partial \\
0 \\
0\end{array}\right|$ & $\begin{array}{l}\widehat{c} \\
0 \\
0 \\
0 \\
0 \\
0 \\
0 \\
0 \\
0\end{array}$ & 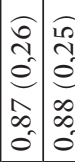 & 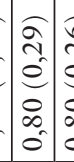 & $\begin{array}{c}0 \\
\text { d } \\
0 \\
0 \\
0 \\
\infty \\
0 \\
0 \\
0\end{array}$ & 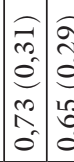 & $\begin{array}{l}0 \\
0 \\
0 \\
0 \\
0 \\
0 \\
0 \\
0 \\
0 \\
0 \\
0 \\
0 \\
0\end{array}$ & $\mid \begin{array}{l}0 \\
0 \\
0 \\
0 \\
10 \\
0 \\
0\end{array}$ \\
\hline
\end{tabular}

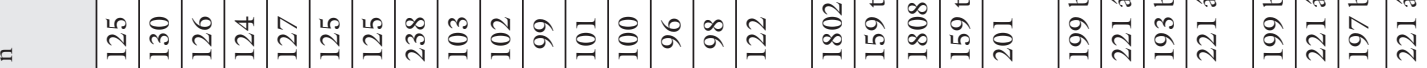

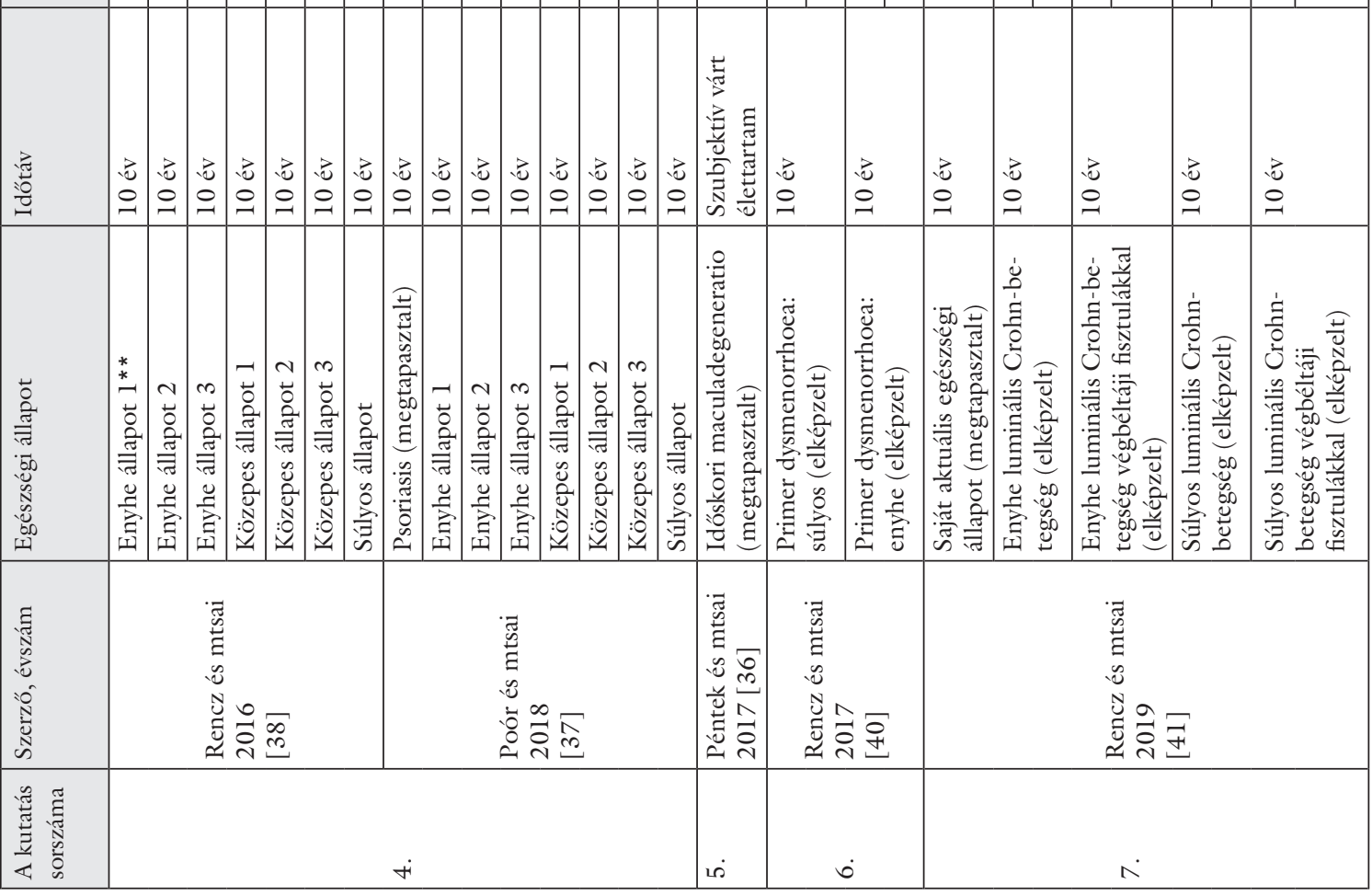

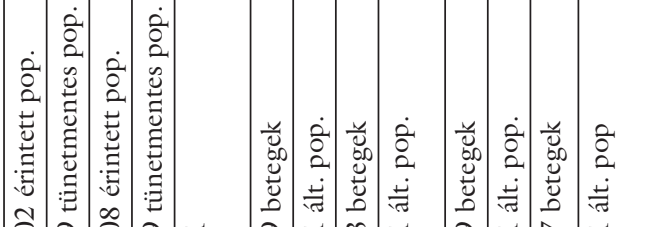


dysmenorrhoea). Nemzetközi szinten számos további, nagy betegségteherrel járó krónikus állapot vizsgálatában alkalmazták már az időalkut, így a cardiovascularis betegségek, a diabetes, az asthma, a daganatos betegségek és a mentális betegségek területén [49], Magyarországon azonban az említett betegcsoportok körében még nem történt ilyen kutatás.

Több nemzetközi összefoglaló közlemény számolt be az időalku használatával kapcsolatos hibákról, illetve a módszertan és az eredmények hiányos közléséről [24, 28]. Az időalku számos változatát alkalmazták már Magyarországon, a kutatók jellemzően törekedtek a vizsgált egészségi állapot vagy betegcsoport jellegéhez igazítani a módszertant. Az elképzelt állapotleírásokat értékeltető hét kutatás mindegyike részletesen közölte az állapotleírásokat (vignetták). A hazai kutatások közül egy alkalmazott 'rosszabb a halálnál' formátumot is, amely megfelel a nemzetközi gyakorlatnak. Egy nemzetközi összefoglaló közlemény alapján az időalku-kutatások 8\%-a használt 'rosszabb a halálnál' formátumot [50]. Csupán két esetben (rheumatoid arthritis és időskori maculadegeneratio) találtunk jelentősebb hiányosságokat a módszertan leírásában és/vagy az eredmények közlésében (például a hasznosságok alapvető leíró statisztikái és a 'non-traderek' aránya). Eredményeink azt mutatják, hogy a magyarországi időalku-kutatások többsége megfelel az alapvető nemzetközi ajánlásoknak és minőségi követelményeknek.

Magyarországon az egészségügyi technológiák költséghatékonysági elemzése törvényileg kötelező [9]. A hatályos egészség-gazdaságtani irányelv akkor javasolja a direkt hasznosságmérési módszerek alkalmazását - köztük az időalkut -, amennyiben egy betegségben az indirekt hasznosságmérési módszerek (például az EQ-5D-kérdóív) bármilyen okból nem alkalmazhatók [9]. A hasznosságértékek adják a QALY életminőségre vonatkozó komponensét, így közvetlenül hatással vannak az új egészségügyi technológiák - például gyógyszerek, gyógyászati segédeszközök, diagnosztikus eljárások költséghatékonyságára és ezáltal társadalombiztosítási támogatásba kerülésére. Eredményeink azt mutatják, hogy egyre több betegségben érhetők el a magyar társadalom és betegek preferenciáin alapuló hasznosságértékek, melyek lehetővé teszik, hogy a költséghatékonysági elemzésekben ne csak a költségadatok, hanem az egészségi állapotra vonatkozó adatok is hazai forrásból származzanak. Mindez várhatóan hozzájárul a hazai egészségügyi technológiaelemzés fokozatos minőségi javulásához és a szakszerű egészségügyi finanszírozói döntéshozatal elősegítéséhez.

A jelen közlemény korlátja, hogy kizárólag időalku módszerrel hasznosságokat közlő publikációkat válogattunk be, eltekintettünk minden, más módszerrel mért hasznosságértéktől (például EQ-5D). A hazai EQ-5Dkutatások eredményei korábbi összefoglaló közleményünkben elérhetők [10]. A hét beválogatott kutatásban mért hasznosságok az eltérő módszertan alkalmazása miatt közvetlenül nem vagy csak korlátozottan hasonlíthatók össze, így az áttekintés folyamán metaanalízist nem végeztünk. Az időalku fejlődésével párhuzamosan más direkt hasznosságmérési módszerek is elterjedtek (például standard játszma), illetve a közelmúltban fokozatosan új direkt hasznosságmérő módszerek is megjelentek, mint a diszkrét választás (discrete choice experiment) vagy a legkedvezőbb-legkedvezőtlenebb skálázás (best-worst scaling) módszere [51, 52]. Az időalku módszer továbbfejlesztésének lehetséges jövőbeli irányai a metodológiai harmonizáció, új módszerek kidolgozása a jelenleg kihívást jelentő, a halálnál rosszabbra értékelt állapotok értékelésére és a digitális technológiák felhasználása a módszer használatának megkönnyítésére.

\section{Következtetések}

A jelen összefoglaló közleményben szisztematikusan áttekintettük a magyarországi, időalku módszerrel közölt kutatások eredményeit. 7 különböző krónikus állapotban 3 időalkutípust használtak eddig hazánkban, ami az orvosszakmai területeket és a módszert tekintve szélesnek mondható. A közlemények nagyobb részben követik a nemzetközi minőségi követelményeket. Az időalku módszer alkalmazása javasolt más krónikus állapotokban is, hogy elősegítsük a magyar társadalom és betegek preferenciáin alapuló egészségügyi technológiákkal kapcsolatos finanszírozói döntéshozatalt.

Anyagi támogatás: A tanulmányt az Innovációs és Technológiai Minisztérium által meghirdetett Tématerületi Kiválósági Program 2020 - Intézményi Kiválóság Alprogram támogatta, a Budapesti Corvinus Egyetem "Pénzügyi és Lakossági Szolgáltatások" tématerületi programja (TKP2020-IKA-02) keretében.

Szerzôi munkamegosztás: A következő feladatokban minden szerző részt vett: a keresési stratégia kidolgozása és a kézirat megírása. A keresés eredményeinek áttekintését B. P. Gy. és R. F. végezte. A közléshez történő előkészítést B. P. Gy. végezte. A cikk végleges változatát mindhárom szerző elolvasta és jóváhagyta.

Érdekeltségek: A szerzőknek nincsenek érdekeltségeik.

\section{Irodalom}

[1] James SL, Abate D, Abate KH, et al., GBD 2017 Disease and Injury Incidence and Prevalence Collaborators. Global, regional, and national incidence, prevalence, and years lived with disability for 354 diseases and injuries for 195 countries and territories, 1990-2017: a systematic analysis for the Global Burden of Disease Study 2017. Lancet 2018; 392(10159): 1789-1858. [Correction: Lancet 2019; 393(10190): e44.]

[2] Torrance GW. Measurement of health state utilities for economic appraisal: a review. J Health Econ. 1986; 5: 1-30.

[3] Torrance GW. Utility approach to measuring health-related quality of life. J Chronic Dis. 1987; 40: 593-603. 
[4] Tsevat J. What do utilities measure? Med Care 2000; 38(9 Suppl): III60-IIl64.

[5] Brazier J, Ratcliffe J, Saloman J, et al. Measuring and valuing health benefits for economic evaluation. 2nd edn. Oxford University Press, 2016.

[6] Weinstein MC, Torrance G, McGuire A. QALYs: the basics. Value Health 2009; 12(Suppl 1): S5-S9.

[7] Schwarzer R, Rochau U, Saverno K, et al. Systematic overview of cost-effectiveness thresholds in ten countries across four continents. J Comp Eff Res. 2015; 4: 485-504.

[8] Rowen D, Azzabi Zouraq I, Chevrou-Severac H, et al. International regulations and recommendations for utility data for health technology assessment. Pharmacoeconomics 2017; 35 11-19.

[9] Ministry of Human Resources issued professional guideline for health technology assessment methodology of cost-effectiveness analyzes. [Az Emberi Erőforrások Minisztériuma szakmai irányelve az egészségügyi technológia értékelés módszertanáról és ennek keretében költséghatékonysági elemzések készítéséről.] Egészségügyi Közlöny 2017; LXVI(3): 821-840. [Hungarian]

[10] Rencz F, Gulácsi L, Drummond M, et al. EQ-5D in Central and Eastern Europe: 2000-2015. Qual Life Res. 2016; 25: 26932710.

[11] Dolan P. Whose preferences count? Med Decis Making 1999; 19: 482-486.

[12] Brazier J, Ara R, Azzabi I, et al. Identification, review, and use of health state utilities in cost-effectiveness models: an ISPOR Good Practices for Outcomes Research Task Force report. Value Health $2019 ; 22: 267-275$.

[13] Arnesen T, Trommald M. Roughly right or precisely wrong? Systematic review of quality-of-life weights elicited with the time trade-off method. J Health Serv Res Policy 2004; 9: 43-50.

[14] Arnesen T, Trommald M. Are QALYs based on time trade-off comparable? - A systematic review of TTO methodologies. Health Econ. 2005; 14: 39-53.

[15] EuroQol Group. EuroQol - a new facility for the measurement of health-related quality of life. Health Policy (Amsterdam) 1990; 16: 199-208

[16] Kennedy-Martin M, Slaap B, Herdman M, et al. Which multiattribute utility instruments are recommended for use in costutility analysis? A review of national health technology assessment (HTA) guidelines. Eur J Health Econ. 2020; 21: $1245-1257$.

[17] Rencz F, Brodszky V, Gulácsi L, et al. Parallel valuation of the EQ-5D-3L and EQ-5D-5L by time trade-off in Hungary. Value Health 2020; 23: 1235-1245.

[18] Tosh JC, Longworth LJ, George E. Utility values in National Institute for Health and Clinical Excellence (NICE) technology appraisals. Value Health 2011; 14: 102-109.

[19] Borsi A. The valuation of the Hungarian quality of life using EQ-5D method. [Magyar életminőség értékek felmérése az EQ-5D módszer segítségével.] IME 2012; 11: 30-33. [Hungarian]

[20] Poór AK, Sárdy M, Cserni T, et al. Assessment of health-related quality of life in psoriasis patients in Hungary. [Psoriasisban szenvedő betegek életminőségének vizsgálata Magyarországon.] Orv Hetil. 2018; 159: 837-846. [Hungarian]

[21] Farkas K, Kolossváry E, Járai Z. Cilostazol improves the quality of life and lower-limb functional capacity also in diabetic patients. [A cilostazol diabeteses betegekben is javítja az életminőséget és az alsó végtagi funkcionális kapacitást.] Orv Hetil. 2020; 161: 1637-1645. [Hungarian]

[22] Tamási L, Speer G. Assessment of patient-reported outcomes by questionnaires in patients with Moderate and severe chronic obstructive pulmonary disease treated with glycopyrroniUm in the reaL lifE setTing in Hungary (AMULET). [Glikopirróniummal kezelt középsúlyos és súlyos krónikus obstruktív tüdőbetegek állapotának kérdőíves értékelése valós körülmények között.
AMULET-vizsgálat.] Orv Hetil. 2020; 161: 295-305. [Hun garian]

[23] Bohner-Beke A, Kőnigné Péter A, Vass L, et al. Hungarian validation of the clubfoot disease-specific instrument. [Dongalábspecifikus életminőség-kérdő́iv magyar adaptációja.] Orv Hetil. 2018; 159: 1269-1277. [Hungarian]

[24] Boye KS, Matza LS, Feeny DH, et al. Challenges to time tradeoff utility assessment methods: when should you consider alternative approaches? Expert Rev Pharmacoecon Outcomes Res. 2014; 14: 437-450.

[25] Attema AE, Edelaar-Peeters Y, Versteegh MM, et al. Time tradeoff: one methodology, different methods. Eur J Health Econ. 2013; 14(Suppl 1): S53-S64.

[26] Xie F, Gaebel K, Perampaladas K, et al. Comparing EQ-5D valuation studies: a systematic review and methodological reporting checklist. Med Decis Making 2014; 34: 8-20.

[27] Janssen BM, Oppe M, Versteegh MM, et al. Introducing the composite time trade-off: a test of feasibility and face validity. Eur J Health Econ. 2013; 14: 5-13.

[28] Wright DR, Wittenberg E, Swan JS, et al. Methods for measuring temporary health states for cost-utility analyses. Pharmacoeconomics 2009; 27: 713-723.

[29] van Nooten F, Busschbach J, van Agthoven M, et al. What should we know about the person behind a TTO? Eur J Health Econ. 2018; 19: 1207-1211.

[30] Kwon J, Kim SW, Ungar WJ, et al. Patterns, trends and methodological associations in the measurement and valuation of childhood health utilities. Qual Life Res. 2019; 28: 1705-1724.

[31] van Hoorn RA, Donders AR, Oppe M, et al. The better than dead method: feasibility and interpretation of a valuation study. Pharmacoeconomics 2014; 32: 789-799.

[32] Moher D, Liberati A, Tetzlaff J, et al. Preferred reporting items for systematic reviews and meta-analyses: the PRISMA Statement. PLoS Med. 2009; 6: el000097.

[33] Arber M, Garcia S, Veale T, et al. Performance of Ovid MEDLINE search filters to identify health state utility studies. Int J Technol Assess Health Care 2017; 33: 472-480.

[34] Hajdu K, Brodszky V, Stalmeier PF, et al. Patient-assigned health utility values for controlled and uncontrolled pemphigus vulgaris and foliaceus. J Eur Acad Dermatol Venereol. 2019; 33: 21062113.

[35] Inotai A, Rojkovich B, Fülöp A, et al. Health-related quality of life and utility in patients receiving biological and non-biological treatments in rheumatoid arthritis. Rheumatol Int. 2012; 32: 963-969. [Epub 2011 Jan 18]

[36] Péntek M, Brodszky V, Bíró Z, et al. Subjective health expectations of patients with age-related macular degeneration treated with antiVEGF drugs. BMC Geriatr. 2017; 17: 233.

[37] Poór AK, Brodszky V, Péntek M, et al. Is the DLQI appropriate for medical decision-making in psoriasis patients? Arch Dermatol Res. 2018; 310: 47-55.

[38] Rencz F, Baji P, Gulácsi L, et al. Discrepancies between the Dermatology Life Quality Index and utility scores. Qual Life Res. 2016; 25: 1687-1696.

[39] Rencz F, Brodszky V, Péntek M, et al. Health state utilities for migraine based on attack frequency: a time trade-off study. Neurol Sci. 2015; 36: 197-202.

[40] Rencz F, Péntek M, Stalmeier PF, et al. Bleeding out the qualityadjusted life years: evaluating the burden of primary dysmenorrhea using time trade-off and willingness-to-pay methods. Pain 2017; 158: 2259-2267.

[41] Rencz F, Stalmeier PF, Péntek M, et al. Patient and general population values for luminal and perianal fistulising Crohn's disease health states. Eur J Health Econ. 2019; 20: 91-100.

[42] Rencz F, Brodszky V, Stalmeier PF, et al. Valuation of pemphigus vulgaris and pemphigus foliaceus health states: a convenience sample experiment. Br J Dermatol. 2016; 175: 593-599. 
[43] Tillinger W, Mittermaier C, Lochs H, et al. Health-related quality of life in patients with Crohn's disease: influence of surgical operation - prospective trial. Dig Dis Sci. 1999; 44: 932-938.

[44] Holko P, Kawalec P, Mossakowska M. Quality of life related to oral, subcutaneous, and intravenous biologic treatment of inflammatory bowel disease: a time trade-off study. Eur J Gastroenterol Hepatol. 2018; 30: 174-180.

[45] Golicki D, Jakubczyk M, Graczyk K, et al. Valuation of EQ-5D5L health states in Poland: the first EQ-VT-based study in Central and Eastern Europe. Pharmacoeconomics 2019; 37: 11651176.

[46] Olariu E, Paveliu MS, Baican E, et al. Measuring health-related quality of life in the general population and Roma communities in Romania: study protocol for two cross-sectional studies. BMJ Open 2019; 9: e029067.

[47] Prevolnik Rupel V, Srakar A, Rand K. Valuation of EQ-5D-31 health states in Slovenia: VAS based and TTO based value sets. Slovenian J Public Health. 2020; 59: 8-17.

[48] Golicki D, Jakubczyk M, Niewada M, et al. Valuation of EQ-5D health states in Poland: first TTO-based social value set in Central and Eastern Europe. Value Health 2010; 13: 289-297.
[49] Paracha N, Abdulla A, MacGilchrist KS. Systematic review of health state utility values in metastatic non-small cell lung cancer with a focus on previously treated patients. Health Qual Life Outcomes 2018; 16: 179 .

[50] Tilling C, Devlin N, Tsuchiya A, et al. Protocols for time tradeoff valuations of health states worse than dead: a literature review and conceptual framework for systematic analysis. Med Decis Making 2010; 30: 610-619.

[51] Cheung KL, Wijnen BF, Hollin IL, et al. Using best-worst scaling to investigate preferences in health care. Pharmacoeconomics 2016; 34: 1195-1209.

[52] Soekhai V, de Bekker-Grob EW, Ellis AR, et al. Discrete choice experiments in health economics: past, present and future. Pharmacoeconomics 2019; 37: 201-226.

(Rencz Fanni dr., Budapest, Fôvám tér 8., 1093 e-mail: fanni.rencz@uni-corvinus.hu)

\section{"Senectus ipsa morbus." (Az öregség már maga is betegség.)}

A cikk a Creative Commons Attribution 4.0 International License (https://creativecommons.org/licenses/by/4.0/) feltételei szerint publikált Open Access közlemény, melynek szellemében a cikk bármilyen médiumban szabadon felhasználható, megosztható és újraközölhető, feltéve, hogy az eredeti szerző és a közlés helye, illetve a CC License linkje és az esetlegesen végrehajtott módositások feltüntetésre kerülnek. (SID_1) 